\title{
Effects of essential oils obtained from wild and cultured forms of thyme (Origanum acutidens) on lung cancer cells membrane
}

\author{
도소e Gökhan \\ Alanya Alaaddin Keykubat University, Faculty of Engineering, Department of Genetic and Bioengineering, Antalya, Turkey
}

Cite this article as: Gökhan A. Effects of essential oils obtained from wild and cultured forms of thyme (Origanum acutidens) on lung cancer cells membrane. J Health Sci Med 2021; 4(4): 445-450.

\begin{abstract}
Aim: Nowadays, studies on the use of medicinal plants and their essential oils in cancer treatment are increasing rapidly and these studies are very important both scientifically and economically. However, the collection of plants from nature causes extinction. Therefore, it is of great importance to cultivate plants, especially endemic species, to reproduce and consume them. In our study, cytotoxic and membrane damaging effects of essential oils obtained from wild and cultured forms of Origanum acutidens (Hand.Mazz.) Ietswaart (Lamiaceae) (O. acutidens), which is endemic to Turkey, on non-small-cell lung cancer (NSCLC) cells H1299 and A549 were compared.

Material and Method: The level of malondialdehyde, an oxidative stress biomarker, was determined in cell lysates. Assessment of cell viability was made by CellTiter-Blue ${ }^{\oplus}$ Cell Viability Assay and 3-(4,5-dimethyl-2-thiazolyl)-2,5-diphenyl-2H-tetrazoliumbromide (MTT) assay after 10- $250 \mu \mathrm{g} / \mathrm{mL}$ concentrations of wild and cultured forms of O. acutidens essential oil treated to H1299 and A549 cells for 24, 48 and $72 \mathrm{~h}$. Malondialdehyde levels were assayed for determining the membrane damaging effects.

Results: Cell viability of $\mathrm{H} 1299$ and A549 cells incubated with essential oils obtained from wild and cultured forms of O. acutidens was found to decrease depending on concentration and time. $179 \mu \mathrm{g} / \mathrm{mL}, 157 \mu \mathrm{g} / \mathrm{mL}$, and $132 \mu \mathrm{g} / \mathrm{mL}$ were calculated as IC50 values of wild form of $O$. acutidens essential oil on $\mathrm{H} 1299$ cells for 24,48 , and $72 \mathrm{~h}$, respectively by MTT assay. $150 \mu \mathrm{g} / \mathrm{mL}, 131$ $\mu \mathrm{g} / \mathrm{mL}$, and $110 \mu \mathrm{g} / \mathrm{mL}$ were calculated as IC50 values of wild form of O. acutidens essential oil on H1299 cells for 24, 48, and 72 h, respectively by resazurin-based assay. $118 \mu \mathrm{g} / \mathrm{mL}, 99 \mu \mathrm{g} / \mathrm{mL}$, and $69 \mu \mathrm{g} / \mathrm{mL}$ were calculated as IC50 values of wild form of $O$. acutidens essential oil on A549 cells for 24, 48, and $72 \mathrm{~h}$, respectively by MTT assay. $98 \mu \mathrm{g} / \mathrm{mL}, 83 \mu \mathrm{g} / \mathrm{mL}$, and $57 \mu \mathrm{g} / \mathrm{mL}$ were calculated as IC50 values of wild form of $O$. acutidens essential oil on A549 cells for 24, 48, and $72 \mathrm{~h}$, respectively by resazurinbased assay. Essential oils obtained from wild and cultured forms of O. acutidens increased malondialdehyde level on both H1299 and A549 cells. The greatest membrane damage was observed in A549 cells treated with wild form of O. acutidens essential oil.

Conclusion: Essential oils obtained from wild and cultured forms of $O$. acutidens had cytotoxic effect on lung cancer cells and it has been demonstrated that they showed this effect by causing membrane damage in cells.
\end{abstract}

Keywords: O. acutidens, essential oil, wild and cultured form, membrane damaging, anticancer

\section{INTRODUCTION}

Many of medicinal and aromatic plants are available thanks to the large differences in Turkey ecology. Species endemism is high in Anatolia provides this plant diversity. $30 \%$ of the species of flora aromatic are plants in Turkey. Aromatic plants are the main sources of essential oils (1). Many drugs with known antineoplastic properties are originated from plants. It is a current issue to investigate the treatment methods against cancer types, which are the most important diseases of our age, and the treatment possibilities with herbal origin chemicals among these methods. The fact that a sufficient treatment method has not been developed for this serious disease causes many speculations about the treatment. There is a huge gap in our country in terms of researching the antineoplastic properties of plant extracts. The most researched aromatic plant is thyme. Plant species belonging to different genera in the same family are called thyme. The genera including the thyme species that are traded and widely used in our country are Origanum, Thymbra, Coridothymus, Satureja and Thymus. Studies on the use of medicinal plants and their essential oils in cancer treatment have gained speed and these studies are so important both scientifically and economically. 
According to the report of the World Health Organization (WHO), lung cancer is the first cancer type causing death in men and the third cancer type in women (2). Among all cancer types, the incidence in women is $9 \%$ while it is $17 \%$ for men. The response to chemotherapy is as low as $30-50 \%$ in patients with non-small cell lung cancer, which constitute $80-85 \%$ of lung cancer cases (3). The failure of anticancer drugs in the treatment of lung cancer, especially NSCLC, reveals the need for the development of new chemotherapeutics.

Approximately $50 \%$ of drugs in clinical trials for anticancer activity have been isolated from natural sources or those associated with them $(4,5)$. Many plant species that are endemic to Turkey disappear over time. However, culturing plants while preserving their biological activity characteristics can prevent the extinction of these plant species. Our aim should be to culture and propagate plants without consuming them and to use cultured plants in drug development. Origanum species, which are aromatic medicinal plants, are unconsciously collected from nature and used as spice, thyme tea and thyme oil. The use of plants in culture can prevent the extinction of endemic species and can enable us to have easy and large amount of plants. Therefore, if we compare the wild and the cultured form in our studies and reveal their effects, we can continue our studies with the cultured form. Thus, we protect the endemic species in nature.

The aim of this study was to demonstrate and compare the cytotoxic and membrane damaging effects of essential oils obtained from wild and cultured forms of O. acutidens in H1299 and A549 cells.

\section{MATERIAL AND METHOD}

\section{Collection of Plant Material}

O. acutidens was collected from Refahiye, Erzincan (1950-2000 m), in Turkey, in July 2017. The taxonomic identification of plant materials were confirmed by a plant taxonomist, Dr. Canan Dulgeroglu from Department of Biology, Akdeniz University, Antalya, Turkey (Voucher no: TR 1019).. The cultured form of O. acutidens was obtained from the Erzincan Directorate of Horticulture and was harvested in July 2017. Our study does not require any ethics committee approval. Our study was performed with cancer cell lines obtained from ATCC.

\section{Isolation of the Essential Oil}

The dried aerial parts of plants $(100 \mathrm{~g})$ collected were submitted to water distillation for $2 \mathrm{~h}$ using a Clevengertype apparatus (Ildam Ltd., Ankara, Turkey) at Molecular Biology Department in Biology in Akdeniz University. The obtained essential oil was dried over anhydrous sodium sulphate and after filtration, stored at $+4^{\circ} \mathrm{C}$ until used in experiments.

\section{Cell Lines and Culture}

The human non-small-cell lung cancer (NSCLC) cell line H1299 and A549 were purchased from the American Type Culture Collection (ATCC). All cells were maintained in Roswell Park Memorial Institute 1640 medium (RPMI 1640) contained $10 \%$ fetal bovine serum (FBS) and $1 \%$ antibiotic-antimycotic solution (penicillin, streptomycin and amphotericin) in a humidified atmosphere containing $5 \% \mathrm{CO} 2$ at $37^{\circ} \mathrm{C}$. For subculturing, cells were harvested after trypsin/ethylenediaminetetraacetic acid (EDTA) treatment at $37^{\circ} \mathrm{C}$. Cells were used when monolayer confluence had reached $75 \%$.

\section{Cytotoxicity Assays}

The cancer cells (10,000 cells/well, monolayer) were plated in a 96-well plate. The next day the cells were treated with different concentrations of wild and cultured forms of $O$. acutidens essential oils (10-250 $\mu \mathrm{g} / \mathrm{mL})$ for 24,48 , and $72 \mathrm{~h}$. At the end of the incubation period, the cytotoxicity of this solution on cancer cells was determined by the CellTiterBlue cell viability assay and 3-(4,5-dimethylthiazol-2yl)-2,5-diphenyltetrazolium bromide (MTT) assay. The CellTiter-Blue cell viability assay is based on the ability of living cells to convert a redox dye (resazurin) into a fluorescent end product (resorufin). Nonviable cells rapidly lose metabolic capacity and thus do not generate a fluorescent signal (6). Following cellular reduction, fluorescence was recorded at $560 \mathrm{~nm}$ (excitation) and $590 \mathrm{~nm}$ (emission) spectrofluorometrically (PerkinElmer LS 55). In the MTT assay, tetrazolium salts such as MTT are metabolized by mitochondrial dehydrogenases to form a blue formazan dye, useful for the measurement of cytotoxicity. Test reagents were added to the culture medium. Briefly, $15 \%$ volumes of dye solutions were added to each well after the appropriate incubation time. After 2 $\mathrm{h}$ of incubation at $37^{\circ} \mathrm{C}$, an equal volume of solubilization/ stop solutions (dimethyl sulfoxide) was added to each well for an additional $1 \mathrm{~h}$ of incubation. The absorbance of the reaction solution at $490 \mathrm{~nm}$ was recorded (7). The data were expressed as average values obtained from eight wells for each concentration. IC50, and IC70 concentrations were calculated. For the calculation of these values, Microsoft Excel software was used. Essential oil was dissolved in $0.5 \%$ dimethyl sulphoxide (DMSO). So we treated $0.5 \%$ DMSO alone to H1299 and A549 cells. The reading taken from the wells with cells cultured with only the medium (untreated cells) was used as a $100 \%$ viability value.

\section{Determination of Malondialdehyde Levels}

Malondialdehyde (MDA) levels were determined after H1299 and A549 cells were exposed to different concentrations of wild and cultured forms of $O$. acutidens essential oils (IC50) for $24 \mathrm{~h}$. They were dissolved in 0.5\% DMSO. So we treated 0.5\% DMSO alone to H1299 and A549 cells. H1299 and A549 cells were plated at a 
density $15 \times 104$ cell/100 mm dishes. Cells were scraped off culture plates with culture medium and were centrifuged $600 \times \mathrm{g}$ for $10 \mathrm{~min}$. The cell pellets were washed with phosphate buffered saline and then sonicated $(3 \times 15 \mathrm{sec})$ in $50 \mathrm{mM}$ potassium phosphate, $\mathrm{pH} 7.2$, containing 1 $\mathrm{mM}$ phenylmethylsulfonyl fluoride (PMSF) and $1 \mu \mathrm{g} /$ $\mathrm{mL}$ of leupeptin and centrifuged at $150,000 \times \mathrm{g}$ for 45 min. The supernatant was used for the determination of malondialdehyde level. Malondialdehyde levels in H1299 and A549 were assayed as described in a previous method (8). This fluorometric method for measuring thiobarbituric acid-reactive substances (TBARS) in supernatant is based on the reaction between malondialdehyde and thiobarbituric acid. The product of this reaction was extracted into butanol and measured at $525 \mathrm{~nm}$ (excitation) and $547 \mathrm{~nm}$ (emission) spectrofluorometrically. Protein was determined by the Bradford method (9) with bovine serum as a standard. The experiment was performed in triplicate and mean values were recorded.

\section{Statistical Analysis}

The results of the replicates were pooled and expressed as mean \pm standard error. Analysis of variance (ANOVA) was carried out. The ANOVA was used to determine whether there are any significant differences between the means of three or more independent (unrelated) groups on some variable. Tukey multiple comparisons tests were used. Significance was accepted at $\mathrm{p} \leq 0.05$ (10). Statistical analyses were performed using the Minitab program Release 13.0.

\section{RESULTS}

Effect of Essential Oils Obtained from Wild and Cultured Forms of Origanum acutidens on the Viability of H1299 and A549 Cells

In this study, cytotoxic effects of wild and cultured forms of O. acutidens essential oils on H1299 and A549 lung cancer were investigated by CellTiter-Blue ${ }^{\otimes}$ Cell Viability and MTT tests. H1299 and A549 cells were submitted to increasing concentrations of wild and cultured forms of $O$. acutidens essential oils for 24,48 and $72 \mathrm{~h}$. The concentrations of essential oils needed to reduce growth by $50 \%$ and $70 \%$, respectively (IC50 and IC70) were calculated using the Linear functions (The equation of a straight line). The essential oil from wild and cultured forms of $O$. acutidens were found cytotoxic in concentration and time dependent manners in H1299 and A549 cells according to both cytotoxicity assays (Figure 1A,B; Figure 2A,B). The essential oil from wild forms of $O$. acutidens was found more effective on A549 cells than essential oil from cultured forms of $O$. acutidens (Figure 1A,B). While the essential oil from cultured forms of $O$. acutidens was found more effective on $\mathrm{H} 1299$ cells than essential oil from wild forms of O. acutidens (Figure 2A,B). After 24, 48 and 72 hours incubations IC50 values were calculated respectively from CellTiter-Blue ${ }^{\oplus}$ Cell Viability test results, for essential oil from wild form of O. acutidens on H1299 cells, 150, 131 and $110 \mu \mathrm{g} / \mathrm{mL}$, for essential oil from cultured form of $O$. acutidens on H1299 cells 80, 69 and $60 \mu \mathrm{g} / \mathrm{mL}$ (Table 1). After 24, 48 and 72 hours incubations IC50 values were calculated respectively from MTT test results, for essential oil from wild form of O. acutidens on H1299 cells, 179, 157 and $132 \mu \mathrm{g} / \mathrm{mL}$, for essential oil from cultured form of $O$. acutidens on H1299 cells 100, 94 and $83 \mu \mathrm{g} / \mathrm{mL}$ (Table 1). Also, after 24, 48 and 72 hours incubations IC50 values were calculated respectively from CellTiter-Blue ${ }^{\circ}$ Cell Viability test results, for essential oil from wild form of $O$. acutidens on A549 cells, 98, 83 and $57 \mu \mathrm{g} / \mathrm{mL}$, for essential oil from cultured form of $O$. acutidens on A549 cells 136, 115 and $102 \mu \mathrm{g} / \mathrm{mL}$. After 24, 48 and 72 hours incubations IC50 values were calculated respectively from MTT test results, for essential oil from wild form of O. acutidens on A549 cells, 118,99 and $69 \mu \mathrm{g} / \mathrm{mL}$, for essential oil from cultured form of O. acutidens on A549 cells 163, 138 and $122 \mu \mathrm{g} /$ $\mathrm{mL}$. The CellTiter-Blue cell viability assay was found to be more sensitive than the MTT assay, so we studied other parameters according to CellTiter-Blue assay results.

\begin{tabular}{|c|c|c|c|c|}
\hline Cells treatments & $\begin{array}{c}\text { Es. oil wild }(\mu \mathrm{g} / \mathrm{mL}) \\
\text { (CellTiter.) } \\
\text { X } \pm \text { S.E }\end{array}$ & $\begin{array}{c}\text { Es. oil wild }(\mu \mathrm{g} / \mathrm{mL}) \\
(\mathrm{MTT}) \\
\text { X } \pm \text { S.E. }\end{array}$ & $\begin{array}{c}\text { Es. oil cultured }(\mu \mathrm{g} / \mathrm{mL}) \\
(\text { CellTiter. }) \\
\text { X } \pm \text { S.E. }\end{array}$ & $\begin{array}{c}\text { Es. oil cultured }(\mu \mathrm{g} / \mathrm{mL}) \\
(\mathrm{MTT}) \\
\mathrm{X} \pm \text { S.E. }\end{array}$ \\
\hline H1299, 24 h, IC 70 & $199 \pm 2.38 \mathrm{f}$ & $239 \pm 2.98 \mathrm{~h}$ & $120 \pm 3.81 \mathrm{c}$ & $287 \pm 3.44 j$ \\
\hline H1299, 48 h, IC 50 & $131 \pm 2.01 \mathrm{c}$ & $157 \pm 2.03 \mathrm{e}$ & $69 \pm 1.04 a$ & $94 \pm 1.23 b$ \\
\hline H1299, 48 h, IC 70 & $179 \pm 3.71 \mathrm{f}$ & $215 \pm 3.11 \mathrm{~g}$ & $116 \pm 1.99 c$ & $151 \pm 1.88 \mathrm{e}$ \\
\hline H1299, 72 h, IC70 & $159 \pm 2.43 \mathrm{e}$ & $191 \pm 2.38 \mathrm{f}$ & $111 \pm 2.41 \mathrm{c}$ & $143 \pm 2.11 d$ \\
\hline A549, 24 h, IC 50 & $98 \pm 1.22 b$ & $118 \pm 1.99 c$ & $136 \pm 2.66 \mathrm{~d}$ & $163 \pm 2.03 \mathrm{e}$ \\
\hline A549, 24 h, IC70 & $149 \pm 2.35 d$ & $179 \pm 2.77 f$ & $185 \pm 2.01 \mathrm{f}$ & $224 \pm 2.78 g$ \\
\hline A549, 48 h, IC 50 & $83 \pm 1.65 a$ & $99 \pm 1.22 b$ & $115 \pm 3.81 \mathrm{c}$ & $138 \pm 2.71 d$ \\
\hline A549, 48 h, IC 70 & $134 \pm 2.66 c$ & $160 \pm 2.88 \mathrm{e}$ & $162 \pm 1.99 \mathrm{e}$ & $194 \pm 2.76 f$ \\
\hline A549, 72 h, IC 50 & $57 \pm 1.00 \mathrm{a}$ & $69 \pm 1.71 \mathrm{a}$ & $102 \pm 1.78 b$ & $122 \pm 3.43 c$ \\
\hline A549, 72 h, IC 70 & $108 \pm 1.99 b$ & $130 \pm 1.89 c$ & $149 \pm 2.11 \mathrm{~d}$ & $178 \pm 2.77 \mathrm{f}$ \\
\hline
\end{tabular}


The Membrane Damaging Effect of Essential Oils from Wild and Cultured form of O. acutidens on H1299 and A549 Cells Membrane

The induction of cytotoxic cell death can be accompanied by membrane and DNA damage. Essential oil induced membrane damage at IC50 concentrations (Figure 3) than those that mediate its anticancer activities. The results of membrane damaging effects of the essential oils (IC50) on H1299 and A549 after $24 \mathrm{~h}$ exposure is shown in Figure 3. Essential oils from wild and cultured form of $O$. acutidens showed membrane damaging effects on both H1299 and A549 cells. The amounts of malondialdehyde (MDA), an end product of lipid peroxidation of membrane, increased almost 2.9 and 2.1

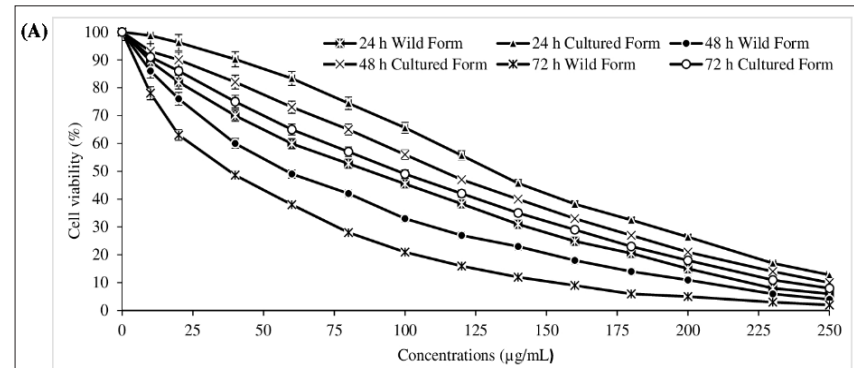

(B)

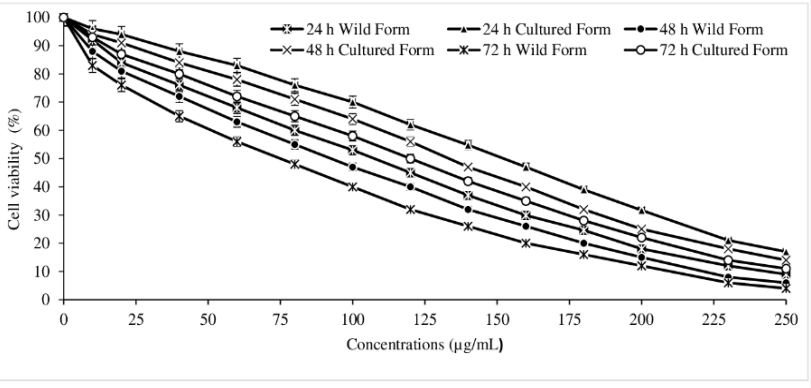

Figure 1. The cytotoxic effects of essential oil from wild and cultured forms of $O$. acutidens on A549 cells after 24, 48 and $72 \mathrm{~h}$ measured by (A) The CellTiter-Blue-Cell Viability Assay; (B) MTT Assay. Results are presented as viability ratio compared with the control group (treated with only the medium-untreated cells). Values are expressed as the mean of three separate experiments \pm S.E. Error bars represent standard error of the mean from three replications. fold in the IC50 concentrations of the essential oil from wild form of $O$. acutidens and essential oil from cultured form of $O$. acutidens treated A549 cells compared to control cells, respectively (Figure 3). While the amounts of MDA increased almost 1.6 and 1.4 fold in the IC50 concentrations of the essential oil from wild form of $O$. acutidens and essential oil from cultured form of $O$. acutidens treated H1299 cells compared to control cells, respectively (Figure 3). The essential oil from wild form of $O$. acutidens caused the most membrane damage in both A549 and H1299 cells. Both the essential oil from wild form of $O$. acutidens and essential oil from cultured form of $O$. acutidens have been shown to cause more membrane damage in A549 than H1299 cells.

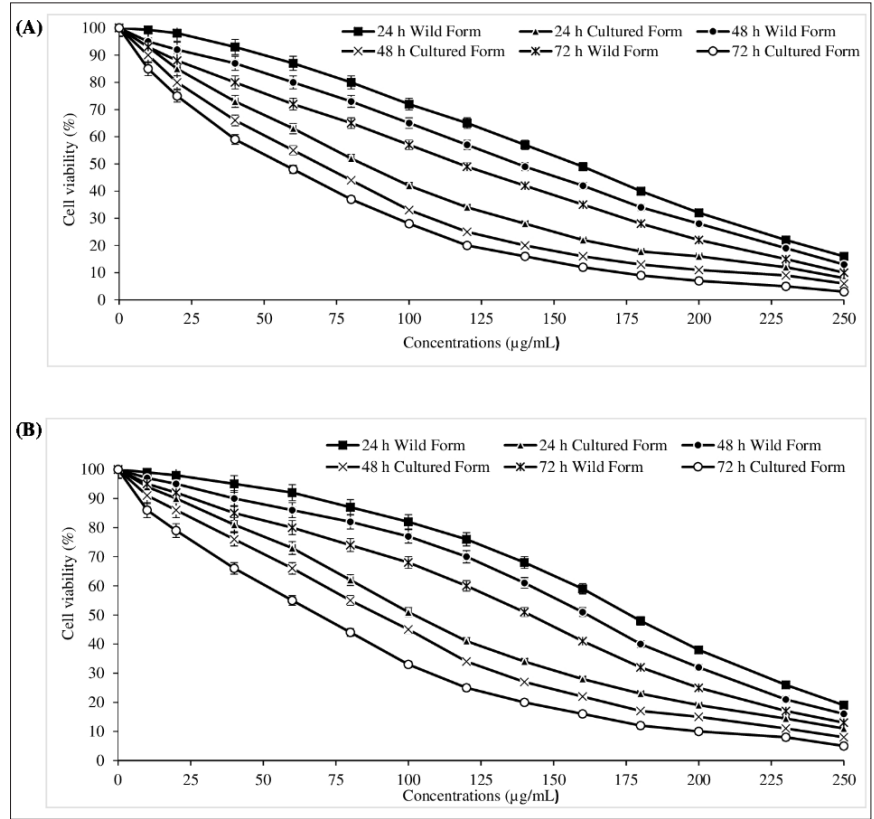

Figure 2. The cytotoxic effects of essential oil from wild and cultured forms of O. acutidens on H1299 cells after 24, 48 and $72 \mathrm{~h}$ measured by (A) The CellTiter-Blue-Cell Viability Assay; (B) MTT Assay. Results are presented as viability ratio compared with the control group (treated with only the medium-untreated cells). Values are expressed as the mean of three separate experiments \pm S.E. Error bars represent standard error of the mean from three replications.

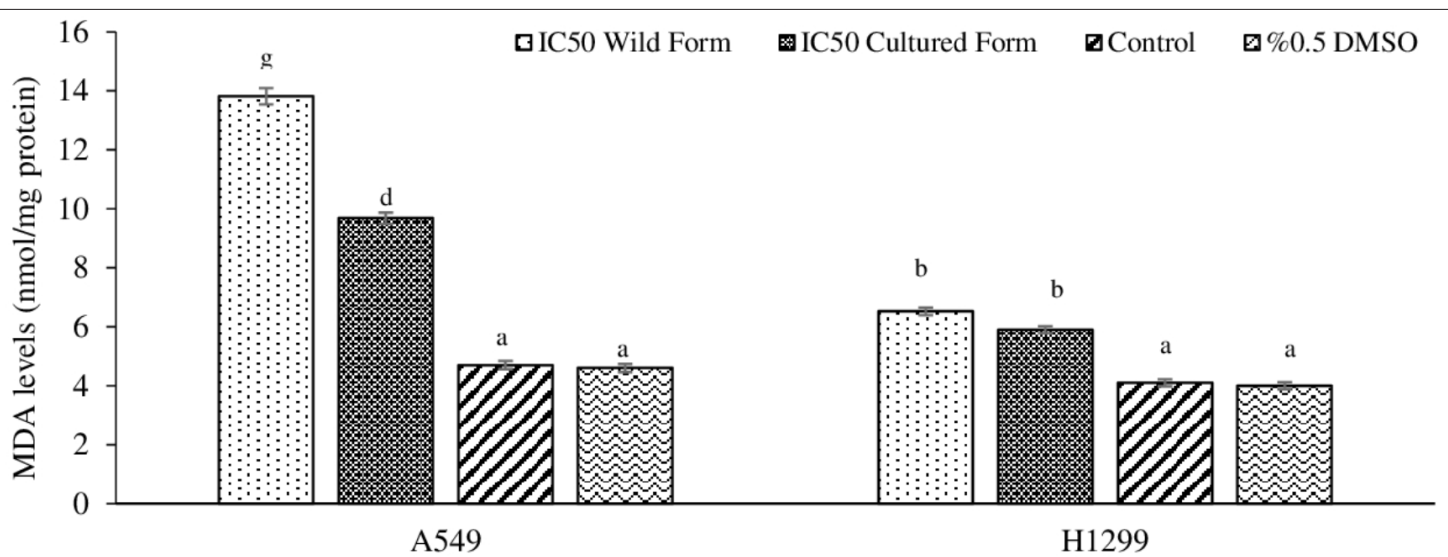

Figure 3. Membrane damaging effects of essential oil from wild and cultured forms of O. acutidens on H1299 and A549 cells. Values are expressed as the mean of three separate experiments \pm S.E. Error bars represent standard error of the mean from three replications, and bars with the same letter indicate no significant difference (ANOVA with Tukey's test, $\mathrm{p} \leq 0.05$ ). Different letters represent significant differences among treatments (ANOVA, p $\leq 0.05$ ) in H1299 and A549 cells. 
In our study, essential oils from wild and cultured form of O. acutidens induced membrane damage and cytotoxicity in both A549 and H1299 cells and this can mediate its anticancer activity. The induction of cytotoxic cell death can be accompanied by membrane damage.

\section{DISCUSSION}

It is very important both scientifically and economically to obtain and evaluate the pure medicinal plants and especially the essential oils of these plants. Many drugs used today with anticancer effect such as vinblastine, irinotecan, topotecan, vincristine were obtained from plants. However, the continuous collection of these plants from nature causes their extinction. Therefore, plants to be used for drug production or other purposes can be cultivated and reproduced. We look for answers to these questions, what kind of differences in the biological action mechanisms of endemic plant species can be caused by the culture and reproduction processes we apply to prevent extinction.

One of the most important mechanisms of used in cancer treatment is apoptosis. Since various chemotherapeutics that act by using apoptotic mechanisms in cancer treatment also damage healthy cells, interest in natural herbal medicines has increased. The plant-derived products are expected to induce lesser side effects compared to synthetic drugs New cancer treatment strategies using endemic plants are increasing day by day.

According to the essential oil content analysis we conducted in another project, carvacrol and p-cymene were determined as the main components of both wild and cultured form of $O$. acutidens. However, while the rate of carvacrol was higher in wild form (Wild: $72.65 \%$; Cultured: $67.98 \%$ ), it was observed that the rate of p-cymene was higher in the cultured form (Wild: 15.19\%; Cultured: $16.01 \%)$. Essential oils, which are lipophilic in nature, show their effects in the cell by crossing the plasma membrane (11). Carvacrol and p-cymene, due to their hydrophobic nature, can react with lipids of the cell membrane and mitochondria, make the membranes permeable and disrupt the structure of the cell (12). Many studies have shown that many essential oils, the main components of which are carvacrol and p-cymene, have similar anticancer effects (13-17). It has been reported that water extract of $O$. acutidens caused cytotoxic and apoptotic effects in breast cancer cells such as MCF-7, MDA-MB-468 and MDAMB-231. At the end of the incubation, it was shown that caspase-7 protein expression and the number of TUNELpositive cells increased, indicating an apoptotic effect (18). The antineoplastic effect of various extracts of $O$. acutidens obtained from Sivas on breast cancer cells (MDA-MB-231, MDA-MB-468) was demonstrated by Trypan blue method (19). The essential oils from wild and cultured form of
Salvia pisidica showed cytotoxicity on H1299 cells24. In other studies, it has been reported that $O$. acutidens essential oil showed antimicrobial activity against different bacterial species $(20,21)$.

By culturing endemic species in different physical conditions, we can make them show similarities with the wild form. It has been reported in many studies that essential oils and their components obtained from plants had anticancer effects by creating cytotoxic effects on cancer cells. In our study, H1299 and A549 cells, which were exposed to essential oils obtained from wild and cultured form of $O$. acutidens for 24, 48 and 72 hours, decreased cell viability due to the increase in concentration.

Free radicals cause cytotoxicity and lipid peroxidation associated with chronic diseases such as cell senescence and cancer. Reactive oxygen species (ROS) are generated inside the cells in response to external stimuli or stress under normal conditions. ROS interacts with the double bonds of the polyunsaturated fatty acids to form lipid hydroperoxide. One of the major secondary oxidation products of peroxidized polyunsaturated fatty acids is malondialdehyde (MDA), which has a mutagenic and cytotoxic effect. The lipid peroxidation caused by free radicals causes changes in the structure, permeability and fluidity of the membrane, impairment of lysosomal balance and induction of apoptosis

Essential oils obtained from wild and cultured form of $O$. acutidens increased MDA levels according to controls in H1299 and A549 cells. Origanum onites (Lamiaceae) essential oil and its two phenolic components, thymol and carvacrol, induced membrane damage on Hep G2 cells (22). Carvacrol, thymol eugenol, eucalyptol, terpinen-4ol, and camphor at higher concentrations increased MDA levels, causing membrane damage, in both parental and epirubicin-resistant H1299 cells $(22,23)$. Also in another study T. revolutus C. essential oil caused to increase MDA levels in Hep G2 cells according to control cells (25).

With our study, it can be suggested as a natural herbal source in the production of new anticancer drugs, since it was revealed that essential oils obtained wild and cultured form of $O$. acutidens had cytotoxic and membrane damaging effects on H1299 and A549 cells. The results of our study will also contribute significantly to the medical literature and the national economy. In addition, taking our naturally grown plants into culture will prevent their extinction. The production of cultured form of $O$. acutidens will contribute to the protection of this endemic plant by preventing its decline or extinction in nature. With the cultivation process, it will be easier to reach this endemic species and it will be available in more abundance. This will significantly reduce the cost of using this plant for therapeutic purposes. 


\section{CONCLUSION}

O. acutidens essential oils may be a hope in the future for lung cancer patients who were tried to be treated with conventional chemotherapy drugs but could not achieve the desired success, in line with the results we obtained from our study. Finally, the new experiences/gains we have gained as a result of our study will also lead to the evaluation of plant-derived compounds in lung and other cancer research.

\section{ETHICAL DECLARATIONS}

Ethics Committee Approval: This study does not require any ethics committee approval. This study was performed with cancer cell lines obtained from ATCC.

Informed Consent: For this type of study, formal consent is not required.

Referee Evaluation Process: Externally peer-reviewed.

Conflict of Interest Statement: The author has no conflicts of interest to declare.

Financial Disclosure: The author declared that this study has received no financial support.

Author Contributions: All of the authors declare that they have all participated in the design, execution, and analysis of the paper, and that they have approved the final version.

Acknowledgements: The authors wish to thanks to Alanya Alaaddin Keykubat University for providing the necessary facilities to conduct this study.

\section{REFERENCES}

1. Yaşar S. Determination of soil properties, fixed and essential oil contents of some perennial medicinal plants that grow naturally in Çukurova University campus. Master Thesis, Çukurova University 2005; 43 pp.

2. World Cancer Research Fund International. Working to prevent cancer worldwide. Available online: www.wcrf.org, 2012

3. Iscan $\mathrm{M}$. The role of metabolic polymorphism in drug resistance in lung cancer. Ankara University Scientific Research Projects, 2007, Ankara.

4. Cragg GM, Newman DJ. Antineoplastic agents from natural sources: achievements and future directions. Expert Opin Investig Drugs 2000; 9: 1-15.

5. Usta J, Kreydiyyeh S, Knio K, Barnabe P, Bou-Moughlabay Y, Dagher S. Linalool decreases Hep G2 viability by inhibiting mitochondrial complexes I and II, increasing reactive oxygen species and decreasing ATP and GSH levels. Chem-Biol Interact 2009; 180: 39-46.

6. Gloeckner H, Jonuleit T, Lemke HD. Monitoring of cell viability and cell growth in a hollow-fiber bioreactor by use of the dye Alamar Blue (TM). J Immunol Methods 2001; 252: 131-8.

7. Mosmann T. Rapid colorimetric assay for cellular growth and survival: application to proliferation and cytotoxicity assays. J Immunol Methods 1983; 65: 55-63.

8. Wasowicz W, Neve J, Peretz A. Optimized steps in fluorometric determination of thiobarbitiric acidreactive substances in serum importance of extraction $\mathrm{pH}$ and influence of sample preservation and storage. Clin Chem 1993; 39: 2522-6.
9. Bradford MM. A rapid and sensitive method for the quantitation of microgram quantities of protein utilizing the principle of protein dye binding. Anal Biochem 1976; 72: 248-54.

10.Kirkman TW. Statistics to use [Online]. 1996 Available:http:// www.physics.csbsju.edu/stats/1996 [17 August 2008].

11. Griffiths DE. Psi-screen, an in vitro toxicity test system: applications in the bioassay of perfumes and fragrance chemicals. Altern Lab Anim 2005; 33: 471-86.

12.Lambert RJV, Skandamis PN, Coote PJ, Nychas GJ. A study of the minimum inhibitory concentration and mode of action of oregano essential oil, thymol and carvacrol. J Appl Microbiol 2001; 91: 453-62.

13. Ozkan A, Erdogan A. A Comparative evaluation of antioxidant and anticancer activity of essential oil from Origanum onites (Lamiaceae) and its two major phenolic components. Turk J Biol 2011; 35: 735-42.

14.Erdogan A, Ozkan A. A comparative study of cytotoxic, membrane and DNA damaging effects of Origanum majorana's essential oil and its oxygenated monoterpene component linalool on parental and epirubicin-resistant H1299 cells. Biologia 2013; 68: 754-61.

15. Sobral MV, Xavier AL, Lima TC, De Sousa DP. Antitumor activity of monoterpenes found in essential oils. Hindawi Publishing Corporation, Scientific World Journal 2014; Article ID 953451: 35 pages.

16. Bayala B. Anticancer activity of essential oils and their chemical components -a review. Am J Cancer Res 2014; 4: 591-607.

17.Essien EE, Newby JM, Walker TM, Ogunwande IA, Setzer WN, Ekundayo O. Essential oil constituents, anticancer and antimicrobial activity of Ficus mucoso and Casuarina equisetifolia leaves. J Essent Oils 2016; 41: 1-6.

18. Tuncer E, Unver-Saraydin S, Tepe B, et al. Antitumor effects of Origanum acutidens extracts on human breast cancer. J Buon 2013; 18: 77-85.

19.Turan M, Sökmen A, Karadayı K, Polat ZA, Şen M. Antineoplastic effects of some plant extracts specific to Sivas region. Cumhur Medical J 2010; 32: 9-18.

20.Kursat M, Emre İ, Yılmaz Ö, Erecevit P. Antioxidant and antimicrobial activity in the seeds of Origanum vulgare L. subsp. gracile (C. Koch) Ietswaart and Origanum acutidens (Hand.Mazz.) Ietswaart from Turkey. Grasas Aceites 2011; 62: 410.

21.Osge B, Turker A, Ipek A, Gurbuz B. Chemical compositions and antibacterial activities of the essential oils from aerial parts and corollas of Origanum acutidens (Hand.-Mazz.) Ietswaart, an endemic species to Turkey. Molecules 2009; 14: 1702-12.

22. Ozkan A, Erdogan A. A comparative evaluation of antioxidant and anticancer activity of essential oil from Origanum onites (Lamiaceae) and its two major phenolic components. Turk J Biol 2011; 35: 735-42.

23. Ozkan A, Erdogan A. Membrane and DNA damaging/protective effects of eugenol, eucalyptol, terpinen-4-ol, and camphor at various concentrations on parental and drugresistant H1299 cells. Turkish J Biol 2013; 37: 405-13.

24. Ozkan A, Erdogan A, Sokmen M, Tugrulay S, Unal O. Antitumoral and antioxidant effect of essential oils and in vitro antioxidant properties of essential oils and aqueous extracts from Salvia pisidica. Biologia 2010; 65: 990-96.

25.Erdogan A, Ozkan A. Effects of Thymus revolutus Célak essential oil and its two major components on Hep G2 cells membrane. Biologia 2013; 68: 105-11. 